\title{
THE COVID-19 PANDEMIC AND THE RIGHTS OF THE INDIVIDUAL IN TERMS OF PRIVATE AND PUBLIC LAW
}

LA PANDEMIA DEL COVID-19 Y LOS DERECHOS DE LA PERSONA EN TÉRMINOS DE DERECHO PÚBLICO Y PRIVADO

\author{
Evgen Kharytonov* \\ Olena Kharytonova** \\ Denis Kolodin \\ Maxym Tkalych ${ }^{* * * *}$
}

Abstract: The principles of adjusting the regulation of civil relations in the
context of the Covid-19 pandemic are analyzed. The admissibility of
restricting human rights in the context of the conflict of private and public
interests are researched. Besides, the authors tried to determine the optimal
algorithm of government actions aimed at preventing the spread of the
epidemic. The main approach to the understanding of human rights in the
article is based on Dworkin's concept of "rights as trumps". A system of such

* Doctor of Legal Science. Professor of Civil Law Department and Head of same Department at National University "Odesa Law Academy" (Odesa, Ukraine). Corresponding Member of National Academy of Law Sciences of Ukraine. Honored Science and Technology Worker of Ukraine. https://orcid.org/0000-0001-5521-0839. zharuton@gmail.com

** Doctor of Legal Science. Professor of Intellectual Property and Corporate Law Department and Head of the same Department at National University "Odesa Law Academy" (Odesa, Ukraine). Corresponding Member of National Academy of Law Sciences of Ukraine. Honored Science and Technology Worker of Ukraine. https://orcid.org/0000-0002-9681-9605. lh2512@gmail.com

*** Ph.D., Associate Professor of Criminal law Department, Head of Civil law and Economic Justice Faculty of National University "Odesa Law Academy" (Odesa, Ukraine). https://orcid.org/0000-0001-6368-0849. kolodinodessa@gmail.com

${ }^{* * * * *}$ Associate Professor of Civil Law Department at Zaporizhzhia National University (Zaporizhzhia, Ukraine). https://orcid.org/0000-0003-4224-7231. maxx.tkalich@gmail.com 
categories as "a man", "a private person", "natural private rights", "private law" and "national civil law" is analyzed. The conclusion is that the importance of the category of "natural" human rights is underestimated, which exacerbates the problem of ensuring human rights in a pandemic, when the state actively uses public law to cope with the crisis. As a result, there is a conflict of basic principles of private and public law: "everything is allowed except what is prohibited by law" vs. "only what is allowed by law is possible". It is proposed to assume that the usual way of the legal existence of a person is that he/she acts as a participant in civil relations of a private type, even in a pandemic. Private relations, which arise during the quarantine period, are proposed to be regulated mainly by private law methods, limiting the influence of the state. This will allow us to reach a compromise of private and public interests, without restricting the rights of individuals voluntarily.

Keywords: Human Rights, Private Person, Private Law, Public Law, Pandemic Covid-19

Resumen: Se analizan aquí los principios de adecuación de la regulación de las relaciones civiles en el contexto de la pandemia Covid-19, así como la admisibilidad de restringir los derechos humanos e individuales, atendiendo al conflicto de intereses públicos y privados. Se busca determinar el algoritmo óptimo de las acciones gubernamentales destinadas a prevenir la propagación de la epidemia, a través de la concepción de los derechos como triunfos de Dworkin y de las nociones de "hombre", "persona privada", "derechos naturales privados", "derecho privado" y "derecho civil nacional". Se concluye que hoy se subestima la categoría de "natural" de los derechos humanos, lo que se agrava durante la pandemia, cuando el Estado utiliza activamente el derecho público para salir de la crisis. Como resultado, existe un conflicto de principios básicos del derecho público y privado: "todo está permitido excepto lo prohibido por la ley" vs. "solo se puede hacer lo permitido por la ley". Se propone que se asuma de forma habitual la existencia jurídica de una persona como partícipe en las relaciones civiles de tipo privado, incluso durante una pandemia. Así, las relaciones privadas que surgen durante el período de cuarentena deben regularse principalmente por las reglas de derecho privado, limitando la influencia del Estado. Esto nos permitirá llegar a un compromiso de los intereses públicos y privados, sin restringir los derechos de las personas de forma voluntaria.

Palabras clave: Derechos Humanos, Persona privada, Derecho Privado, Derecho Público, Pandemia Covid-19 
Summary. I. Introduction. II. Analysis of recent research and publications, which initiated the solution of the problem. III. Highlighting the unresolved parts of the overall problem. IV. Results and discussion. IV.1. Covid-19 Pandemic and Private \& Public Legal Means of Overcoming its Consequences. IV.2. Avoidance of Cognitive Dissonance. IV.3. the Problem of Maintaining the Leading Role of Civil Law in the Legal Existence of Society in Quarantine. V. Conclusions. References.

\section{INTRODUCTION}

The Covid-19 pandemic has become one of the greatest challenges of the 21 st century, affecting virtually all aspects of human existence.

Back in 2015, during a speech at the annual international TED conference (a platform where "ideas worthy of dissemination" are discussed), Bill Gates called on humanity to spend money, especially on the fight against dangerous viruses. Warning that humanity was not ready for the next outbreak of the epidemic, he showed by the example of the Ebola virus that the problem of combating it was the lack of a system to overcome the epidemic. It was a failure on a global scale. The fact that the disease almost did not spread beyond the three countries of West Africa was simple luck. Next time it may not be so lucky.

Assessing the potential danger in monetary terms, Gates recalled that the World Bank estimates that a global flu epidemic would lead to a drop in global welfare of more than 3 trillion dollars and the loss of many millions of lives. However, such data were given by him, not for intimidation, but to emphasize that Ebola has given humanity a good lesson: it served as an early warning, a warning signal. If we start preparing now, we will be fully armed (Gates, 2015).

Unfortunately, the speech of Bill Gates did not gain enough resonance and humanity did not manage to meet the coronavirus in full armor. The outbreak of the coronavirus SARS-CoV-2, which causes Covid-19, was first spotted in the Chinese province of Hubei in late 2019. In some months infection with the virus was recorded in more than 130 countries, including Ukraine. Since March 11, the World Health Organization (WHO) has recognized the spread of the disease as a pandemic. WHO President Tedros Adan Gebreis said the Covid-19 pandemic was accelerating at an exponential rate. For the first 100 thousand cases, it took 67 days. The second 100 thousand took eleven days. The third 100,000 took only four days. The fourth 100,000 took only two days. According to him, without aggressive precautionary measures in all countries, millions could die (Gates, 2020). 
As of June 6, according to the Worldometers (2020), the total number of confirmed cases of Covid-19 in the world was 6,918,902; the total number of deaths due to the coronavirus pandemic is 400.078; a total of 3,386,274 patients recovered from the disease.

If at the end of February investors believed that the outbreak would affect only the Chinese economy, then with the rapid increase in the number of diseases and the transition of the epidemic to a pandemic, there was an increase in threats in the humanitarian and economic spheres. According to some economists, the result of a pandemic could be a radical change in world development trends, in particular, the weakening of integration processes and the strengthening of the positions of "nationalists". The crisis has highlighted the risks of international integration and has led to "legitimate national restrictions" on global trade and flows. These restrictions make countries' economies national and their policies nationalist.

Although the bans were considered a temporary pandemic, many acknowledge that the crisis caused by the spread of the coronavirus will be long-term. It disrupts international supply chains and adds popularity to antimigrant policies. This weakens globalization. The epidemic has shown that it is not always possible to rely on one's neighbors and allies during a crisis. This strengthens the confidence of those who believe in a strong government and the priority of public needs over individual freedom and national interests over international cooperation. After a pandemic, proponents of globalization will have a long time to explain to others why it is important (Koshlyak \& Spirin, 2020).

In the humanitarian field, the "crisis administration" of states has led to restrictions on several human rights, as well as the rights of the individual. Importantly, although the bans and restrictions were supposed to be temporary, no one could have predicted how long the crisis would last and what its real scale would be. This threatens the "habituation" of society to solve problems through public administration, in the absence of a proper regulatory framework. Moreover, there is currently no holistic concept of regulating relations in the context of an epidemic/pandemic. Describing the situation when «most European countries are gradually getting out the quarantine needed to fight the new coronavirus», Dempsey (2020) said that "this was an amazing period during which the state seriously interfered in the life of people, imposing many restrictions unheard for democracies in peacetime. Even more surprising is how citizens resigned themselves to this intervention".

As a result, it can be stated that the consequence of the pandemic was a challenge to the very vision of the essence of the regulation of relations in the field of private law. 
Since the pandemic in the social sense is a challenge to society as a whole and each individual, it exacerbates the conflict of public and private interests: if the individual cares primarily about himself, the community about itself as a system. Therefore, there is a problem of admissibility of restriction of the rights of an individual, which is considered here in the context of the mentioned conflict of private and public interests. From a practical point of view, this looks like an assessment of the justification of the government's actions aimed at combating the epidemic, which suppresses the rights of individuals.

Such a challenge cannot be left unanswered by researchers, in particular jurists: studying, analyzing and resolving problems that have arisen in connection with the epidemic and quarantine, in particular, preparing proposals for the interpretation and application of current legislation and practice; improvement of norms governing civil relations in special conditions, etc.

Regarding the problem of the correlation between private and public law, in this paper we will deliberately focus the reader's attention on the differences between these two legal phenomena. We are aware that in accordance with modern trends in law, there is a gradual interpenetration of private and public law, but for post-socialist countries, including Ukraine, it is extremely important to understand the essence of private law. During the Soviet occupation of Ukraine and the dictatorship of the Communist Party, the existence of private law was, in fact, denied. Administrative-command economy used administrative methods of regulating social relations. Due to the denial of private law and private law methods of legal regulation as of 1991 in Ukraine there were no such basic institutions of private law as the institute of private property law, a full-fledged institute of civil law contract, the institute of entrepreneurial activity, etc. With the return of Ukraine's independence and the beginning of the development of a modern state on the basis of a market economy, there was a need to restore a clear division of the legal system into private and public law, because only in this way it was possible to restore the lost institutions at both the doctrinal and legislative levels. Moreover, Ukraine has historically been part of the family of Romano-Germanic countries that recognize the division of law into public and private. Without a clear understanding of such a division, it is very difficult to reform the domestic economy and social life in general.

The legislator also agrees with the need to restore the role of private law in our society and, accordingly, introduced the principles of "everything that is not prohibited by law is allowed" (for individuals), as opposed to the principle "everything is prohibited by law what is not allowed" (for public 
figures) at the level of the constitution of the state. Article 19 of the Constitution of Ukraine (1996) stipulates that

«The legal order in Ukraine is based on the principles according to which no one may be compelled to do what is not provided by law. Public authorities and local governments, their officials are obliged to act only on the basis, within the powers and in the manner prescribed by the Constitution and laws of Ukraine».

\section{ANALYSIS OF RECENT RESEARCH AND PUBLICATIONS, WHICH INITIATED THE SOLUTION OF THE PROBLEM}

Although the emergence of the coronavirus was said to be a surprise to mankind, research on the subject has already appeared in the field of jurisprudence. Thus, on April 20, 2020, Columbia University published a monograph "Law in the Time of Covid-19", which examines various aspects of the creation of law and its functioning in a pandemic: threats to human rights, public life and social assistance, privacy, problems in the economy. The introduction of this book contains the hope that jurists in the United States and other countries will follow the example of its authors and share their thoughts and ideas in these difficult times (Pistor, 2020).

On April 23, 2020, on the basis of the Faculty of Civil and Economic Justice of the National University "Odesa Law Academy" (2020) an online conference was held on the problems of legal regulation of civil relations in the context of the pandemic Covid-19.

It should also be emphasized that the problem of human rights in general is the subject of many studies by both domestic and foreign wellknown researchers. Among the foreign scholars who once shaped and continue to shape the current debate in the field of human rights are Hohfeld (1917), Harris (1997), Waldron (2013), Hart (2015), MacCormick (1982), Dworkin (1977), and Gewirth (1981).

The concept of human rights has been described as «one of the greatest inventions of our civilization [which] can be compared in its impact on human social life to the development of modern technological resources and their application to medicine, communication, and transportation» (Wacks, 2012, p. 239). Similar acclaim abounds. Though the concept first emerges in the Middle Ages, the recognition in the seventeenth and eighteenth centuries of the secular notion of human rights was plainly a significant intellectual moment in history. The concept makes little sense unless it is understood as fundamental and inalienable, whether or not such rights are legally recognized and regardless of whether they emanate from a "higher" natural law. 
The legal recognition of human rights in the twentieth century occurred when the United Nations, in the grim shadow of the Holocaust, adopted the Universal Declaration of Human Rights in 1948. This document and the International Covenants on Civil and Political Rights, and Economic, Social and Cultural Rights in 1976, demonstrate, even to the most skeptical observer, a commitment by the international community to the universal conception and protection of human rights.

Our principal concern is, of course, with right-based theories. Professor Dworkin's "rights thesis" argues for the primacy of rights over considerations of the general welfare. This view of "rights as trumps" justifies their protection on a complex exclusion of 'external preferences'.

In this study, we will rely on a similar postulate: the good of the individual is an absolute value and cannot be neglected in favor of the ephemeral common good. In this case, protecting the rights of the individual, we automatically protect the rights of the social group as a set of individuals (Wacks, 2012).

\section{HIGHLIGHTING THE UNRESOLVED PARTS OF THE OVERALL PROBLEM}

The purpose of the article is determined taking into account the current situation. It can be formulated as defining the principles of adjusting the concept of regulation of civil relations in the context of integration processes, which are accompanied by a collision of public and private approaches related to the crisis caused by the Covid-19 pandemic.

The objectives of the article are to establish the admissibility of restrictions on human rights in the context of the conflict of private and public interests, as well as to determine the optimal algorithm of government actions aimed at preventing the spread of the epidemic.

The methodological basis of the study is the classical provisions for determining the relationship of personality, state, and law, formulated by Savigny (2011): in public law, the whole state is the goal, and the individual is subordinate, while in private law, each individual is the goal, and every legal relationship concerning its existence or special position is only a means.

From this point of view, we consider human rights as a "right in the subjective sense", which is understood as the priority of the human will, aimed at a particular good or interest. This priority is recognized and protected by law and order. Individual interests are divided into those that are established primarily for individual purposes and those that are 
established primarily for public purposes. Recognized primarily for the public interest, the individual interest is the content of public law. Subjective public law is a right that belongs to an individual on the basis of his status as a member of the state. Taking into account the priority of the will, we can distinguish two types: dürfen (desire, aspiration) and können (possibility). Dürfen means "to have the desire to dare to do something". In this case, the rule of law recognizes the relevant actions of the individual permitted, it allows the individual will to exercise its freedom in certain areas. Können means "to be able". Private subjective law includes both dürfen and können, and public subjective law contains only können. Public rights are not those that are allowed, but only those that are granted by the authorities (Jellinek, 2004). Therefore, they are not part of the natural freedom, regulated by the law, but the extension of the rights of natural freedom. Thus, considering human rights as the rights of an individual, we build a system of categories: "man", "private person", "natural private rights", "private law" and "national civil law".

\section{RESULTS AND DISCUSSION}

\section{IV.1. Covid-19 Pandemic and Private \& Public Legal Means of Overcoming its Consequences}

The problem of the conflict of private and public interests, of course, has existed before. But in the context of the normal existence of the EU, there was a tendency to give considerable freedom of action to participants in civil relations and the courts (Smith, 2012). General principles of civil relations, trade in the EU were to be determined on the basis of the Draft Common Frame of Reference (DCFR) (2010). Their task was to provide a basis for a single concept of private law in accordance with the basic values of European civilization. Such values should be taken into account by all European countries when determining the directions of development of national legislation.

However, pandemic conditions are forcing states to resort to the use of public coercion, as aggressive action is needed to contain any infectious pathogen, especially an infectious one such as Covid-19. Protective measures, such as business closures or social distancing, are only effective when combined with rigorous, systematic efforts to prevent the spread of the disease. For example, in Singapore, South Korea, and other countries that have stopped the spread of coronavirus, uncompromising approaches have provided success, including mass testing, contact tracking, and selective quarantine, which, for example, the United States has not imposed. Thanks 
to government's efforts in Singapore, the spread of the infection was stopped, hospitals did not face a strong influx of new patients, and only three people died from the disease (Hazeltine, 2020).

The effectiveness of public remedies for overcoming the crisis is a powerful incentive to expand their scope. However, assessing the progress in stopping the spread of the virus in this way, experts warn that if the partial restriction of citizens' rights and the expansion of law enforcement powers will take a long time, both the government and the people will get used to it. The state will dominate more, it will determine the patterns of people's behavior. After overcoming the pandemic, the authorities can continue to use these tools. China is already pursuing such a policy. There is a danger that liberal countries may also follow the same path - developing programs to track people, their contacts and gain unauthorized access to personal data - not only correspondence and surveillance cameras, but also personal biometric (Amelin, 2020).

Such a threat is evidenced by the restriction of a number of human rights during the establishment and in the process of quarantine, which gave scientists reason to talk about "A New Struggle over Privacy, Data Protection and Human Rights" (Mendos Kuskonmaz, 2020).

As a result, the conflict between human rights and the right (and obligation) of public administration to take measures to ensure epidemiological safety is exacerbated.

It is proposed to resolve this conflict on the basis of proportionality: mass surveillance and generalized search and surveillance systems can be introduced only if they are proportional to the goal they seek to achieve.

«Respect of the principle of proportionality is the key in this context: mass surveillance and generalized tracing and tracking systems should only be introduced if they are proportionate to the objective sought and designed to comply with fundamental rights and the principle of proportionality» (Mitsilegas, 2020).

This position, in our opinion, is rational, but at the same time it does not seem specific enough. In fact, it reproduces the general understanding of law (requirements for law), which was formed in the days of ancient Rome: Ius est ars boni et aequi. After all, aequi can be translated as "justice" and as "adequacy". However, the methodological basis for determining the "proportionality" (adequacy) of the restriction of human rights, the individual remains unclear. Moreover, the researchers do not pay attention to the possibility/ability of an individual to be a participant in relations in both the private and public spheres.

Therefore, from a practical point of view, it seems more justified to talk about resolving the conflict of private (human rights) and public interest 
on the basis of a reasonable compromise. This means that government regulations on epidemiological security (including administrative means) can be considered an acceptable way to regulate public relations, provided that these government regulations comply with the Natural Law. In turn, ensuring such compliance is based on relevant international acts, norms of national legislation (first of all, Constitutions).

However, if the Constitution of Ukraine and international acts ratified by Ukraine form a sufficiently reliable regulatory framework for human rights, the provisions of the Civil Code of Ukraine (2003) in this area, as evidenced by the situation arising from the pandemic, do not meet modern challenges. And this creates a serious problem (which is specific not only for Ukraine). It is worth noting that, although the Prime Minister of Ukraine, Shmygal, acknowledged that the government «faced a historic challenge and had to resist the spread of the pandemic and at the same time prevent a largescale economic crisis in the country», but the government did not propose a clear program and specific mechanism to overcome the crisis, related to the pandemic (NV.ua, 2020).

In particular, on April 6, 2020, the Cabinet of Ministers of Ukraine introduced a number of restrictive measures related to the imposed quarantine throughout Ukraine (Resolution No 255 of April 2, 2020). It was forbidden to:

(i) stay in public places without wearing personal protective equipment, including a respirator or protective mask, including self-made;

(ii) move in a group of more than two people, except in cases of official necessity and accompaniment of persons under 14 years of age, parents, adoptive parents, guardians, trustees, foster parents, or adult relatives of the child;

(iii) stay in public places of persons under 14 years of age, unaccompanied by parents, adoptive parents, guardians, trustees, foster parents, or adult relatives of the child;

(iv) visits to educational institutions by its applicants;

(v) visiting parks, squares, recreation areas, forest parks and coastal areas, except for walking pets by one person and in case of business necessity;

(vi) visiting sports and children's playgrounds;

(vii) conducting all mass (cultural, entertainment, sports, social, religious, advertising and other) events, except for measures necessary to ensure the work of public authorities and local governments, provided that participants are provided with personal protective equipment, including respirators or protective masks, including self-manufactured, as well as compliance with appropriate sanitary and anti-epidemic measures; 
(viii) work of business entities, which provides for the reception of visitors, including catering establishments (restaurants, cafes, etc.), shopping and entertainment centers, other entertainment establishments, fitness centers, cultural institutions, trade and consumer services;

(ix) regular and irregular transportation of passengers by road in urban, suburban, intercity, intra-regional and inter-regional communication, in particular passenger transportation on city bus routes in the mode of a route taxi,

(x) transportation of passengers by subways of Kyiv, Kharkiv and Dnipro;

(xi) transportation of passengers by rail in all types of domestic communication (suburban, urban, regional and long-distance);

(xii) visits to institutions providing palliative care, social protection, in which children, elderly citizens, war and labor veterans, persons with disabilities, persons with persistent intellectual or mental disabilities, institutions providing temporary or permanent residence/social services to families/individuals in difficult life circumstances, except for institutions and establishments that provide services in an emergency (crisis);

(xiii) visiting points of temporary stay of foreigners and stateless persons who are illegally staying in Ukraine, and points of temporary accommodation of refugees, except for persons providing legal assistance to persons staying in such places;

(xiv) be outside without identity documents, citizenship or special status; and,

(xv) to leave places of observation (isolation) without permission.

So, from the point of view of human rights, the most affected were: restrictions on the right to respect for private life; restriction of the right to liberty and security of person - forced placement of citizens in observation; restrictions on the right of citizens to freedom of movement: prohibition for certain categories to move across the state border and checkpoints, cancellation of transport links; restriction of the right to freedom of peaceful assembly, prohibition to gather more than a certain number of people; restriction of the right to education, ban on attending educational institutions; restriction of the right to freedom of religion, prohibition of religious events; restriction of the right of access to medical care, temporary suspension of planned hospitalization measures and planned operations, except for urgent ones.

Is it possible to restrict freedom in an emergency? Yes, but a good reason is needed. This fundamental principle of the rule of law is reflected in the Convention for the Protection of Human Rights and Fundamental Freedoms (1950; hereinafter the "Convention"), namely: Articles 8 to 11 
provide for interference with fundamental rights where necessary in a democratic society.

Article 15 of the Convention also provides for a derogation from certain rights, namely:

«Any High Contracting Party may take measures derogating from its obligations under this Convention only to the extent required by the urgency of the situation and provided that such measures shall not be inconsistent with its other obligations under international law».

First of all, the reaction of the state during an emergency situation should be based on factual data, and not due to political pressure or the need to do something. There must be a clear scientific and medical justification for emergency measures.

No less important is the need to use the legislation to achieve the ultimate goal. It is necessary to prove that the recommendations, soft commitments and restrictive measures will not work and the enforcement of a quality law is necessary.

In the light of the case law of the European Court of Human Rights (hereinafter "ECtHR") on the violation of such rights in the context of Article 15 of the Convention, whenever an applicant complains that his rights under the Convention have been violated during the derogation period, the Court first examines whether the measures taken can be justified under the main articles of the Convention; and only if they cannot be justified in this way does the Court proceed to determine whether the waiver was lawful (for example, Lawless v. Ireland (1960) (§ 3), § 15).

The ECtHR in its explanations on the application of Art. 15 of the Convention stated that due attention was paid to such factors as: the nature of the rights affected by the waiver, the circumstances giving rise to the emergency and its duration (Brannigan and McBride v. The United Kingdom (1993, § 43 A). and Others v. The United Kingdom (2009, § 173); whether ordinary legislation would be sufficient to deal with the threat posed by public danger; whether the measures are a real response to the emergency; whether the measures were used for the purpose for which they were authorized; whether safeguards against abuse were provided.

Thus, in the context of the restriction of rights on the territory of Ukraine and the justification of the limits of interference with such rights, it is necessary to establish whether there was indeed a public danger, whether adequate measures were taken in relation to the threat and whether national legislation was sufficient.

As for the public interests, perhaps, the spread of the virus was curbed, but the economy suffered significant damage. In the second quarter of 2020, 
Ukraine's real Gross Domestic Product (GDP) decreased by $11.4 \%$ year on year (compared to the first quarter of 2019) and by $9.9 \%$ seasonally adjusted (The National Bank of Ukraine, 2020; compared to the first quarter of 2020).

The economic downturn was due to both the direct impact of strict quarantine restrictions on economic activity and indirect - due to uncertainty about the further development of the pandemic situation. As a result, the consumer behavior of citizens has changed in the direction of reducing the purchase of goods and services not essential and investment behavior of enterprises, in the direction of postponing business projects:

- household consumption expenditures decreased for the first time since 2015 (by $10.4 \%$ year on year);

- public sector consumption slowed down by $1.7 \%$;

- gross fixed capital formation decreased by $22.3 \%$ (investment decline continued due to weakening external and domestic demand, uncertainty of the legal framework for certain sectors, including alternative energy, and further development with the spread of morbidity); and,

- exports of goods and services decreased by $9 \%$ year on year, but at a much slower pace than imports, which decreased by $23.4 \%$.

The National Bank noted that in the second quarter of 2020, the performance of all sectors of the economy deteriorated.

In the third quarter, the NBU expects a gradual economic recovery.

This will be facilitated not only by softer quarantine conditions, but also by a revival of external demand and an intensification of domestic consumption. However, economic activity will be constrained by the persistence of certain restrictions in adaptive quarantine, as well as increased risks of further increase in the incidence of coronavirus.

Thus, we emphasize once again that the current situation requires the improvement of the legal provision of human rights of an individual in such a way as to reach a reasonable compromise of private and public interests.

In solving this problem, one of the key - is the concept of "individual right". In clarifying its essence, we should note that the term "right of an individual" can be used in two senses: (i) as a right belonging to a particular person; and, (ii) as a set of rules that determine the status of an individual.

Let us consider each of them further, starting with the basic element "private person", meaning that it is a person who is not a participant in the state and is not endowed with power over other persons.

It should be noted that when considering the problems of human rights violations in a pandemic (introduction of quarantine, etc.) it is often only a matter of restricting "human rights". However, the notion of "violation of 
the rights of an individual" is broader, as it includes quarantine violations of the rights of organizations that may also act as "individuals". At the same time, experts note that in Ukraine, out of 4.5 million people employed in small and medium-sized businesses, more than 1 million are at risk of losing their jobs. Largely due to the actions of the authorities, which imposed quarantine restrictions. It was against small businesses that they found themselves most discriminatory, while large companies received preferences. As a result, many industries were quarantined from small players, turning large operators into monopolists. As a result, competition will suffer, which will affect consumer prices, reduce product quality and narrow the range (Babenko \& Kravchenko, 2020). In other words, the interests of both individuals and non-state companies are affected by quarantine. At the same time, we mean that the basis of the concept of "individual" is still an understanding of it, as a person, because corporations, in fact, is a properly organized and designed set of people.

\section{IV.2. Avoidance of Cognitive Dissonance}

In order to avoid cognitive dissonance, we further proceed from the fact that the usual way of legal existence of a person-individual is his/her participation in civil relations of a private type.

At the same time, as mentioned, since the successes of countries that have used aggressive action and severe restrictions to overcome Covid-19 raise hopes for the effectiveness of public law, encouraging the regulation of relations between individuals by public law, it is necessary to address conflicts of interest. Significant here are the considerations that, although the government in a pandemic makes many decisions, the legitimacy of which is quite questionable, but the struggle for positivist legitimacy does not preclude support for government decisions insofar as they comply with the laws of natural law and common sense. Such a dramatic dilemma always arises in extreme situations (wars, natural disasters, urgency, etc.) (Kostenko, 2005).

To verify the veracity of this impression, we should consider the peculiarities of the participation of the individual in the legal relations of the private and public spheres, having previously focused on the properties of these spheres.

The most common criterion for distinguishing between private and public law, which was once used by Ulpian and became known through the Digests of Justinian (1998), is the establishment in the first and second cases of "specific weight" of human (private) and state interests. It has been repeatedly used by modern jurists. In terms of assessing the direction of 
protection of interests, private law protects the private interests of individuals, and public law the interests of the state, general, public interests.

Thus, the sphere of public law is, first of all, a question of subordination of one person to another, a question of competence of state bodies and officials, on the one hand, - and, on the other, - passive, as a rule, legal personality of subordinates, their duties and responsibilities arising from government acts of state bodies and officials. In the private sphere, the legal personality of participants in civil relations is equally active and is based on the principles of legal equality, their freedom of will and initiative in establishing legal relations, and then the implementation of their respective subjective rights and responsibilities.

Characteristic features of private law, as a regulator of public relations, is that it: (i) regulates relations between individuals (Rabinovich, 2010; Kostenko, 2020); (ii) recognizes the priority of the interests of the individual; (iii) protects the private interest from the arbitrariness of the state; (iv) ensures the free expression of the will of the subjects in the exercise of their rights; (v) prefers contractual forms of regulation of relations; (vi) contains norms that are "addressed" to the subjective right and provide protection of the latter; (vii) widely uses dispositive norms; and, (viii) defines a lawsuit as the main procedure for protecting the interests of an individual.

The sources of private law that affect the understanding of its essence and further characterize its content are: (i) natural law, as a basis for determining the status of a private person; (ii) national legal systems that determine the principles of protection of the rights of an individual; (iii) conflict rules, which provide for compromises in determining the status of an individual in different legal traditions and national legal systems; (iv) international legal agreements relating to these issues; and, (v) the concept of Roman private law: «Roman law was seen as a treasury from which to obtain legal ideas and principles to meet new needs» (Berman, 1998), and «which provided legal technique, as well as material rules of the past, which were revived by virtue of their authority and urgent need» (Anners, 1994).

On this basis, private law is defined as a concept, a set of ideas, allusions, impressions, emotions, aspirations that arise in determining the status of the individual as the basic value of civilization.

Private law, like public law, is a supranational system of law. Instead, civil law is a manifestation of private law at the level of national legal systems, acting as a branch of national law (civil law in the objective sense, positive civil law).

It should be noted that the division of law into private and public is a scientific abstraction, which allows to characterize in general terms the two 
main areas of legal regulation of public relations. Therefore, the analysis of the category of private law, as a rule, is accompanied by a description of public law, which is defined as a set of legal institutions, rules and regulations that are the basis for the functioning, in a way, a structured organizational system, through which the use of the imperative method achieves the goal of public order and ultimately - the implementation and protection of human rights (Kharytonova, 2004). Based on this understanding of the essence of private and public law one can establish their importance for the regulation of certain relations, the nature of the ratio of public or private elements in their regulation.

When establishing restrictions on movement, determining the order of work, treatment, first of all, the collective interest is taken into account, the imperative method of legal regulation is applied, and the principles of public law are applied.

On the other hand, civil relations between individuals, even in the conditions of quarantine, can be regulated by agreements, using the dispositive method, and arise on the initiative of the parties. As for private property relations, the right of private property cannot be legally limited. However, its "actual restrictions" may be the result of quarantine restrictions, such as the movement of people, which makes it impossible for the owner to use things that belong to him/her, and so on.

Under quarantine, real social relations are a subject to regulation on the basis of private or public law, depending on the specific content of certain relations. To regulate relations with the participation of an individual, the norms of branches of national legislation, first of all, civil and administrative law, are used, which are the result of reflections of the concepts of private and public law at the level of national legal systems. Respectively, civil law and administrative law methods of legal regulation are used.

The method of civil law regulation includes dispositive (authorizing) and imperative means of influencing the participants in civil relations, having, however, the basis of the principles of legal equality of the parties, justice, good faith and reasonableness. When using the dispositive means of the civil law method, civil relations are regulated with the participation of an individual and regulatory civil legal relations arise, which act as civil relations regulated by the agreement of the parties or norms of law (Kharytonov \& Kharytonova, 2018).

The peculiarity of regulatory civil legal relations in the private sphere, in our opinion, is their dual nature. This is expressed in the fact that in the "positive" regulation of civil relations, there is a "granting" of civil rights and responsibilities to the participants of these relations, in accordance with 
the established norms and rules of conduct of civil rights. In this case, the "normative" basis of their occurrence can be both the rules of civil law and the rules of natural law. At the same time, regulatory civil legal relations may arise as a result of the implementation of the civil function of authority, through which the regulatory framework is created - the prerequisites for self-regulation in the field of private law. Due to this specific civil law function, the participants of civil relations can determine for themselves the rules of conduct, create de facto regulations of local action, and so on. Its conceptual basis is the well-known Roman private law sentence "Everything is allowed that is not prohibited by law". Therefore, civil rights and obligations arise on this basis under certain conditions.

\section{IV.3. the Problem of Maintaining the Leading Role of Civil Law in the Legal Existence of Society in Quarantine}

One of the important problems of ensuring the rights of the individual in a pandemic, and especially in quarantine, is to maintain the leading role of civil law in the legal existence of society. In the context of an epidemic/pandemic, public law is most actively used by many states to stop it and prevent its harmful effects. This leads to the emergence of administrative (organizational and security) legal relations, which have their legal grounds for the rules of prohibition, and the actual basis, a violation of the prohibitions and restrictions provided by these rules. Administrative protection legal relations are both internal and external. They have an internal character when they arise in connection with the need to protect the rights of participants in administrative relations in case of their violation, and external, when they arise on the basis of administrative law, which provide sanctions for violations of public order. In particular, this situation occurs when determining the consequences of violating the rules and regulations relating to quarantine and encouraging their observance through the application of administrative sanctions. It is the result of a standard approach used by the authorities to combat the pandemic by legal means: stopping its spread, preventing harmful consequences, and so on. At the same time, as it is a matter of applying methods of public influence on participants of various (including civil) relations, the threat of unjustified restriction and other violations of subjective rights of an individual who is involved in administrative relations as an object of influence increases significantly.

As a result, there is a conflict of basic principles of private and public law: "everything is allowed except what is prohibited by law" and "only what is allowed by law is possible". In the case of an individual, in the case 
of a democratic state governed by the rule of law, the recognition of the primacy of the individual's interests over the interests of the state should be maintained even in a crisis related to a pandemic. This forces the public authorities to restrict the rights of the individual with caution and with appropriate reservations. The position of the Minister of Justice of Ukraine Denys Malyuska is indicative in this situation. In an interview with Radio Liberty on the question of whether there were violations of the rights of citizens guaranteed by the Constitution during the quarantine, the Minister said that disputes related to the illegality of acts of the Cabinet, corporate decisions, decisions of legal entities and other administrative acts, "will be decided by the court" (Kuznetsova, 2020). Thus, the advantage is recognized not by administrative but by judicial decision.

It should be noted that due to the fascination with the simplicity of public influence and the hope of quickly overcoming the threats associated with the pandemic and its consequences, the opportunities for civil law influence on the formation of behavior of individuals in quarantine remain untapped. In particular, it is overlooked that non-contractual, protective obligations play an important role in ensuring the protection of the rights and interests of participants in civil relations. Meanwhile, the use of civil law to achieve the goal of quarantine in an epidemic/pandemic, has the advantage that allows to reach a compromise of interests of the participants on an adversarial basis, without trying to limit the rights of individuals voluntarily.

We should remember that even Roman law was aware of the obligations of "quasi ex delicto", which were based on the threat of harm to others (Cesare, 2000). Based on the fact of creating such a threat (for example, placing something over the place where people walk (The Digests of Justinian, 1998)) praetor gave everyone (every interested person) the socalled "public" ("popular" (The Digests of Justinian, 1998)) claim actio de positis vel suspensis. Such a lawsuit was filed in the interests of the Roman people. If it had been granted the guilty person would have to pay a fine of 10,000 sesterces (Puhan \& Polenak-Akimovskaya, 1999; García Garrido, 2005).

The civil codes of some countries (including Ukraine) provide for obligations arising from the threat of harm. In particular, quasi-torts are mentioned as the basis for obligations in Chapter II of Section II of Book Three of the French Civil Code. "Danger torts" are provided by the Code of Tort Law of the United States (Zweigert \& Ketz, 1998), although their characteristics are closer, in our opinion, to understanding the source of increased danger.

Chapter 81 of the Civil Code of Ukraine contains provisions on noncontractual obligations arising from the threat to life, health, property of an 
individual or property of a legal entity. These commitments seem to be specifically designed to resolve the "behavioral" conflict of individuals in quarantine in an epidemic/pandemic.

These obligations are a protective legal relationship, as they aim to protect civil rights and interests in the event of actions that pose a threat (in our case - a violation of quarantine rules). Their subjects are the one who created the danger and the one whose interests are threatened by the danger created by the debtor. In general, they can be both individuals and legal entities. But the subject matter of specific obligations depends on the objects being threatened. In the case of a threat to health (as in the case of violation of quarantine rules), the creditor can only be an individual. He/she can file a lawsuit. The basis of the obligations is the fact of endangering the civil rights and interests of others due to non-compliance with the rules of quarantine and, as a consequence, the threat of coronavirus infection). The content of the obligations includes the right of the creditor to demand the elimination of the threat from the person who creates it, and the obligation of the latter to eliminate the danger. Elimination of danger can consist both in the cessation of actions that create danger, and in the commission of actions, if the threat of harm is the result of inaction of the official, who should provide peace to others.

The consequences of not eliminating the threat to life, health, property of an individual is the possibility of the creditor to use several types of means to influence the debtor. In particular, Article 1164 of the Civil Code provides that the creditor has the right to demand immediate measures to eliminate such a threat, compensation for damage, prohibition of activities that pose a threat. Although this rule does not directly indicate the approximate nature of the requirements that may be submitted by the creditor, but the Art. 16 of the Civil Code states that it is possible to use other means of protection of civil rights of a person whose interests are in danger due to improper behavior of another person. Thus, a person whose interests are in danger may demand either the immediate elimination of the threat or the prohibition of activities that pose a threat in the future (which in some way allows him to protect himself from the recurrence of violations that constitute a threat).

The most effective form of protection of the rights of an individual in such cases is compensation for damage caused to his interests as a result of failure to eliminate the threat. In this case, the right of the person concerned to claim compensation for the damage may be exercised in cases where as a result of the threat and its failure to eliminate the danger life and health are harmed (property or non-property).

Article 1165 of the Civil Code establishes only the general principles of compensation for damage caused by failure to eliminate the threat. It 
provides that such damage is to be compensated "in accordance with this Code", thus referring to the general provisions on obligations arising from the infliction of damage (Chapter 82 of the Civil Code). Thus, in this case, there may be two types of protective legal relations: (i) legal relations of protection against the threat posed by civil rights and interests; and, (ii) legal relations of compensation for damage.

It follows from the norms contained in Chapters 81 and 82 of the Civil Code that the conditions for the occurrence of obligations to compensate for damage caused by failure to eliminate the threat are:

(i) The occurrence of property (material) or non-property damage. There may be cases when, as a result of the same action, both damages may occur at the same time, and the encroachment on non-property good entails material damage, together with non-property, and vice versa.

(ii) Illegal action or inaction, which created a threat of harm. Illegality is a legal manifestation of the harmfulness of the conduct (action or inaction) of the offender. When there is a threat of harm to subjective law, interest, the norm of objective law, which protects these interests, is violated. The behavior of someone who has threatened the interests of another person is harmful because it violates someone else's property or non-property interest. In addition, it is illegal because it violates the rules that protect this interest.

(iii) The causal link between the wrongful act or omission that created the danger and the damage suffered by the person concerned. In such obligations, the condition of liability is a "double" causal link. First, there is the causal link between the misconduct and the risk of harm to another person. Second, it is a causal link between the danger created and the damage caused by not eliminating the danger.

(iv) The fault of the person who created the danger of causing harm. At the same time, the creation of danger by illegal behavior in itself creates a presumption of guilt of the person who created the danger (Kharytonov \& Golubeva, 2008). The amount of damage to be compensated is determined in accordance with the rules of Chapter 82 of the Civil Code (Kharytonov, Kharytonova \& Golubeva, 2010).

So why are these norms of the Civil Code of Ukraine practically not applied in the conditions of epidemic/pandemic of coronavirus?

First, obviously, it is the above-mentioned apparent simplicity and effectiveness of public remedies, and hence the conviction of the government (and much of society) to quickly achieve a positive result with their help.

Secondly, it may be a sign of a low level of legal culture and legal literacy of government officials and society. 
Finally, it can be assumed that the mechanism for filing threats to eliminate the threat is not effective enough. This defect could be remedied by introducing so-called "popular" claims, such as those that existed in ancient Rome. With their help, any citizen could file a lawsuit to eliminate the danger that threatened not only him but also other citizens (Kharytonov, 2016).

\section{CONCLUSIONS}

1. The Covid-19 pandemic with its risks of restricting human rights (individual) has become a challenge, necessitating more attention to defining a person's status as an individual and ensuring his or her rights, in particular protection from unjustified restrictions.

2. In resolving related legal issues, we consider it appropriate to proceed from the following. The central figure of civil law is a private person who: (i) is not a participant in the state; (ii) is not in a relationship of powersubordination to other individuals; and, (iii) freely and equally with other persons determines for themselves the rights and responsibilities in relations, arising on its initiative.

3. First of all, a person is a private person. But they can also be organizations (legal entities) created by people as individuals.

4. At present, the category of "natural" human rights, which constitute the most important element of its general status, belongs to private law and exists, regardless of whether they are recognized as an objective right or not. They are objective because of their naturalness and inalienability from man. In the private sphere, the legal personality of the parties is the same and is based on the principles of legal equality, their freedom of will and initiative in establishing legal relations, and then - the implementation of their respective subjective rights and responsibilities.

5. These provisions relate to the scope of private and public law as abstract categories, which are distinguished in the theory of law for scientific analysis. However, this approach is not correct in order to clarify a person's position under national law, as the latter reflects the competition of public and private law principles.

6. A promising direction for improving national civil law, in our opinion, is that the status of an individual as a legal form of a set of basic natural human rights should be enshrined in the Constitution, the rules of which in this area are the implementation of natural law at the national level. At the same time, the legal status of a private person should also be reflected 
in the Civil Code, where it is appropriate to devote a separate section/book "Man as a private person" to these issues.

7. The priority task of updating the Ukrainian civil legislation, in particular, the Civil Code of Ukraine, due to the pandemic should be to determine the private legal status of a person that would meet European standards in this area. Its improvement must be carried out by compromise, taking into account the conflicts between the rights and interests of the individual, on the one hand, and the collective interests, on the other, that arise in extreme situations. The purpose of updating the relevant norms should consider, first of all, the maximum protection of human rights and interests as an individual. 


\section{REFERENCES}

Amelin, A. (2020). The government will control the people more, hiding behind their security. Gazets.ua. In https://gazeta.ua/articles/opinions-journal/_vladasilnishe-kontrolyuvatime-narod-prikrivayuchis-jogobezpekoyu/958662?utm_source=gravitec\&utm_medium=push\&utm_campaign $=$.

Anners, E. (1994). History of European Law. Moscow: The science.

Australia. (1811). The Civil Code. In https://www.trans-lex.org/602100/_/austrian-civilcode/.

Babenko, M. \& Kravchenko, V. (2020). First flowers. Ukrainian business is summing up the results of the quarantine, which has not ended yet. Focus. In https://focus.ua/economics/456848-itogi-karantina-biznes.

Berman, G. J. (1998). Western tradition of law: the era of formation. Moscow: Publishing House of Moscow State University.

Cesare, S. (2000). Roman Private Law Course. Moscow: Publishing house BEK.

Convention for the Protection of Human Rights and Fundamental Freedoms as amended by Protocols $\mathrm{n}^{\circ} 11$ and 14 (1950).

Dempsey, J. (2020). How the Coronavirus Revived Angela Merkel. Carnegie Europe. In https://carnegieeurope.eu/strategiceurope/81763.

Durant, W. (1994). Caesar and Christ: A History of Roman Civilization and of Christianity from Their Beginnings to A.D. 325 (Story of Civilization). New York: Fine Communications.

Dworkin, R. (1977). Taking Rights Seriously. London: Duckworth.

European Court of Human Rights. (1960). LAWLESS v. IRELAND. In https://hudoc.echr.coe.int.

European Court of Human Rights. (1993). Brannigan and McBride V. The United Kingdom. In https://hudoc.echr.coe.int.

European Court of Human Rights. (2009). A. and Others v. The United Kingdom. In https://hudoc.echr.coe.int/fre\#\{\%22itemid\%22:[\%22001-57819\%22]\}.

Faculty of Civil and Economic Justice of the National University "Odesa Law Academy". (2020). Problems of legal regulation of civil relations in the conditions of Covid-19. Odesa: Phoenix.

France. (1804). The Civil Code. In https://www.trans-lex.org/601101/_french-civil-code$2016 /$.

Gaius (n.d). Institvtiones or Institutes of Roman Law. In https://droitromain.univgrenoble-alpes.fr/Anglica/gai2_Poste.htm.

García Garrido, M. J. (2005). Roman private law: cases, lawsuits, institutions. Moscow: Statute. 
Gates, B. (2015). The best lessons in fighting the epidemic can be learned from the experience of preparing for war. Ukrinform. In https://www.ukrinform.ua/rubric-world/2911665-bill-gejts-2015-najkrasi-urokiu-borotbi-z-epidemieu-mozna-distati-z-dosvidu-pidgotovki-do-vijni.html.

Gates, M. (2020). Coronavirus Pandemic 'Accelerating at an Exponential Rate,' Straining Healthcare and Security. ASIS International. In https://www.unn.com.ua/uk/news/1860252-glava-vooz-pandemiyakoronavirusu-priskoryuyetsya-z-eksponentsiynoyu-shvidkistyu.

Gewirth (1981). The basis and content of human rights. Nomos, 23, 119-147. In https://www.jstor.org/stable/24219090?seq=1.

Goykhbarg, A.G. (1924). Fundamentals of private property law. Moscow: Publishing house "Krasnaya nov". In https://naukaprava.ru/catalog/297/4673/28455.

Harris, J. W. (1997). Legal philosophies. London: Butterworths. In https://search.library.uq.edu.au/primoexplore/fulldisplay/61UQ_ALMA2196374890003131/61UQ.

Hart, H. L. A. (2015). The Concept of Law. Oxford: Oxford University Press.

Hazeltine, W. (2020). Why the United States loses the war with Covid-19. Project Syndicate. In https://www.project-syndicate.org/commentary/united-statescovid-testing-contact-tracing-by-william-a-haseltine-202003 ?barrier=accesspaylog.

Hohfeld, W.N. (1917). Fundamental Legal Conceptions as Applied in Judicial Reasoning. The Yale Law Journal, 26(8), 710-770. In https://www.jstor.org/stable/786270?seq=1\#metadata_info_tab_contents.

Jellinek, G. (2004). General Doctrine of the State. Santi Petersburg: Publishing House "Legal Center Press".

Kharytonov, E. \& Golubeva, N. (eds.) (2008). Civil law. Kharkiv: Odissey.

Kharytonov, E. \& Kharytonova, O. (2018). Regulatory legal relations: private law and public law dimensions. Odessa: Helvetica.

Kharytonov, E. (2009). The system (structure) of private law. Legal life of modern Ukraine, 1, 325-326.

Kharytonov, E. (2016). Basics of Roman Private Law. Odesa: Phoenix.

Kharytonov, E., Kharytonova, O. \& Golubeva, N. (eds.). (2010). The Civil Code of Ukraine. Kyiv: Alerta.

Kharytonova, O.I. (2004). Administrative and legal relations (problems of theory). Odessa: Legal Literature.

Koshlyak A. \& Spirin, E. (2020). The world after the pandemic: globalization is weakening, nationalists are strengthening their positions. In https://thebabel.com.ua/texts/40815-svit-pislya-pandemiji-globalizaciyaslabshaye-nacionalisti-zmicnyuyut-poziciji-perekazuyemo-stattyu-foreignpolicy?utm_source=page\&utm_medium=publication. 
The Covid-19 Pandemic and the Rights of the Individual in Terms of Private and Public Law

Kostenko, O. (2005). Natural and human factors in law: research from the standpoint of social naturalism. Bulletin of the National Academy of Sciences of Ukraine, 8, 25-35. In http://nbuv.gov.ua/UJRN/vnanu_2005_8_4.

Kostenko, O. (2020). In the light of social naturalism. Kyiv: Palivoda.

Kuznetsova, I. (2020). On the legality of quarantine, "red" and "black" prisons, raiding and photos under the table - an interview with the Minister of Justice. Radio Svoboda. In https://www.radiosvoboda.org/a/denys-maliuska/30655377.html.

MacCormick, N. (1982). Legal Right and Social Democracy: Essays in Legal and Political Philosophy. Oxford: Clarendon. In https://philpapers.org/rec/MACLRA.

Mendos Kuskonmaz, E. (2020). Covid-19: A New Struggle over Privacy, Data Protection and Human Rights? European Law Blog. In https://europeanlawblog.eu/author/elifkuskonmaz/.

Mitsilegas, V. (2020). Responding to Covid-19: Surveillance, Trust and the Rule of Law. London: Queen Mary University of London. In https://www.qmul.ac.uk/law/news/responding-to-covid-19/items/responding-tocovid-19-surveillance-trust-and-the-rule-of-law.html.

NV.ua. (2020). "We have faced a historic challenge." Shmygal summed up the first 100 days of his Cabinet's work - a video of the government meeting. In https://nv.ua/ukr/ukraine/politics/pershi-100-dniv-roboti-kabminu-zasidannyauryadu-10-chervnya-novini-ukrajini-

50093216.html?utm_campaign=Dailypayukr\&utm_content=803899501\&utm _ medium=Dailypay\&utm_source=email.

Pistor, K. (2020). Law in the Time of Covid-19. New York: Columbia Law School. In https://scholarship.law.columbia.edu/books/240.

Principles, Definitions and Model Rules of European Private Law. Draft Common Frame of Reference (DCFR). (2010). In

https://www.ccbe.eu/fileadmin/speciality_distribution/public/documents/EURO PEAN_PRIVATE_LAW/EN_EPL_20100107_Principles_definitions_and_mo del_rules_of_European_private_law_-

_Draft_Common_Frame_of_Reference__DCFR_.pdf.

Puhan, I. \& Polenak-Akimovskaya, M. (1999). Roman Law. Moscow: Zertsalo.

Rabinovich, S.P. (2010). Yusnaturalism in private law (Western European tradition). Kyiv: Research Institute of Private Law and Entrepreneurship of the National Academy of Legal Sciences of Ukraine.

Romovska, Z. (2005). Ukrainian Civil Law: General Part. Kyiv: Attica. In https://www.twirpx.com/file/448890/.

Savigny. F. K. (2011). System of Modern Roman Law. Miami: HardPress.

Smith, J. (2012). European private law as a mixed legal system. European law, 2(4), 215 225. In http://www.irbis-nbuv.gov.ua/cgibin/irbis_nbuv/cgiirbis_64.exe?I21DBN=LINK\&P21DBN=UJRN\&Z21ID=\&S 
$21 \mathrm{REF}=10 \& \mathrm{~S} 21 \mathrm{CNR}=20 \& \mathrm{~S} 21 \mathrm{STN}=1 \& \mathrm{~S} 21 \mathrm{FMT}=\mathrm{ASP} \_$meta $\& \mathrm{C} 21 \mathrm{COM}=\mathrm{S} \& 2$ _S21P03=FILA=\&2_S21STR=evrpr_2012_2-4_21.

The Digests of Justinian. (1998). Pennsylvania: University of Pennsylvania Press. In http://nbls.soc.srcf.net/files/files/Civil\%20II/Texts/Digest\%20of\%20Justinian, $\% 20$ Volume\%202\%20(D.16-29).pdf.

Ukraine. (1996). Constitution of Ukraine. Kiev.

Ukraine. (2003). The Civil Code. In https://zakon.rada.gov.ua/laws/show/435-15.

Ukraine. Cabinet of Ministers. (2020). Resolution 255. In https://zakon.rada.gov.ua/laws/show/255-2020-\%D0\%BF\#Text.

Ukraine. The National Bank of Ukraine. (2020). Comment of the National Bank on the change in real GDP in the second quarter of 2020. In https://bank.gov.ua/ua/news/all/komentar-natsionalnogo-banku-schodo-zminirealnogo-vvp-u-ii-kvartali-2020-roku.

United Nations. (1948). Universal Declaration of Human Rights. In https://www.un.org/en/universal-declaration-human-rights/.

United Nations. (1976). International Covenants on Civil and Political Rights, and Economic, Social and Cultural Rights.

United States of America (1959). The Code of Tort Law. In https://www.law.cornell.edu/uscode/text/28/part-VI/chapter-171.

Wacks, R. (2012). Understanding jurisprudence: An Introduction to Legal Theory. New York: Oxford University Press.

Waldron, J. (2013). Is Dignity the Foundation of Human Rights? NYU School of Law, Public Law Research Paper, 12, 73-103. In https://papers.ssrn.com/sol3/papers.cfm?abstract_id=2196074.

Worldometers. (2020). In https://www.worldometers.info/coronavirus/.

Zweigert, K. \& Ketz, H. (1998). An Introduction to Comparative Law in Private Law. Moscow: International relationships. In https://www.twirpx.com/file/139935/. 